ANDRZEJ B. ZAKRZEWSKI

\title{
Kierowanie obradami sejmików Wielkiego Księstwa Litewskiego (XVI-XVIII w.)
}

\author{
Die Führung der Kreistagsberatungen im Großherzogtum Litauen \\ in 16.-18. Jahrhundert
}

1. Podstawa żódłowa. Stan badań. 2. Zagajenie sejmikowych obrad. sejmikami: 3.1. W stolicach województw; 3.2. W stolicach powiatów. 3. Zasady kierowania wylaniania sejmikowego dyrektora.

6. Sprzeciwy wobec dyrektora 4. Wyjątki.

5. Tryb i wątpliwości.

1. Quellen. Der Zustand der Forschungen. 2. Die Einleitung der Kreistagsberatungen. 3. Prinzipien der Kreistagsführung: 3.1. In Hauptstädten der Woiwodschaften; 3.2. In Kreisstädten. 4. Ausnahmen. 5. Die Weise der Berufung zum Kreistagsdirektor (der die Beratungen leitete). 6. Einsprüche gegen den Kreistagsdirektor. 7. Schlussfolgerungen und Zweifel.

1. Podstawowe zagadnienia sejmików Wielkiego Księstwa Litewskiego są - zasadniczo - opracowane. W znacznej części było to dziełem Iwana Lappy - profesora w Dorpacie, Pradze i Kownie ${ }^{1}$. Niektóre poglądy tego zasłużonego badacza można niekiedy, w świetle nowych materiałów, zmodyfikować, częściej - pogłębić.

Ponieważ pamiętników opisujących przebieg sejmikowych obrad jest niewiele, a sejmikowe diariusze są rzadkością, warto sięgnąć do jeszcze jednego źródła. Podstawą rozważań będą, poza kilkoma pamiętnikami (zwłaszcza Diariuszem Marcina Matuszewicza), sejmikowe lauda i instrukcje - zarówno wydane, jak i pozostające w rękopisie. Warto bowiem zwrócić uwage na kończące je podpisy. Nierzadko, zwłaszcza $w$ drugiej połowie XVII w. i stuleciu następnym, dokumenty te zawierają komplet podpisów wszystkich (spotyka się to raczej w źródłach z XVIII w.) lub autografy co przedniejszych uczestników. Nie należy jednak mieć nadmiernych złudzeń

\footnotetext{
${ }^{1}$ Kowieński okres jego działalności omówił niedawno A. R a g a u s k a s, Istorikas Ivanas Lappo (1869-1944) ir Lietuva, Lietuvos istorijos metraštis 1993, s. 81-91.
} 
co do możliwości oceny za ich pomocą liczebności sejmikujących. W pamiętnikach $\mathrm{z}$ epoki można bowiem spotkać zarzuty, że konkurenci manifesta klamliwe pisali, fabrykujac podpisy szlachty niebylej nawet na sejmikach ${ }^{2}$. Jeśli podpisy zbierano jednocześnie na kilku kartach, na górze każdej z nich podpisywała się szlachta utytułowana, niżej zaś - nie piastująca urzędów. Czasem niepiśmienni sejmikujący skladali podpisy w formie krzyżyków. Pod tekstem jednak, w lewym górnym rogu - uznawanym za miejsce najgodniejsze - spotykamy zazwyczaj podpisy sejmikowych marszałków. Łączono je najczęściej $\mathrm{z}$ informacją o piastowanym stale urzędzie, rzadziej - o przewodniczeniu obradom.

W kopiach tych dokumentów występuje niekiedy wyszczególnienie autografów przedniejszych uczestników, zakończone: $i$ urzędników ziemskich, grodzkich $i$ szlachty niemalo ${ }^{3}$ względnie: $i$ inszych $P$ [anów] niemalo ${ }^{4}$. Podpisy owe mogą więc ukazać pewne prawidłowości w praktyce kierowania obradami.

$\mathrm{W}$ tej kwestii nie ma jednak reguły. Przywilej wileński z 30 grudnia 1565 r. nie zajmował się organizacją sejmików. Ograniczył się do stwierdzenia, że ma się to odbywać tym że prikładom i poriadkom, jako na takich sojmiech powietowych sprawa, postupok $i$ obyczaj zachowywajetsia $w$ panstwie naszom Korunie Polskof. Również kolejne Statuty nie zajmowały się organizacją obrad.

Reforma administracyjna połowy XVI w. wprowadziła jednolity podział Wielkiego Księstwa Litewskiego na województwa, tych z kolei na powiaty. Powiat był nie tylko - jak w Koronie - jednostką sądową, ale również administracyjną, wojskową i sejmikową. $\mathrm{Na}$ czele urzędniczej hierarchii województwa stali senatorowie: wojewoda i kasztelan, powiatu zaś - odmiennie niż w Koronie - marszałek powiatowy i chorąży. Na czele powiatu będącego stolicą województwa stał wojewoda będący jednocześnie tamtejszym starostą ${ }^{6}$, a miejscowa hierarchia urzędnicza była uboższa o marszałka powiatowego.

\footnotetext{
${ }^{2}$ Pamiętniki Józefa Kossakowskiego, wyd. A. Darowski, Warszawa 1891, s. 176. Nie zawsze były to zarzuty bezpodstawne. Wśród 273 podpisów pod laudum sejmiku grodzieńskiego z 8 II 1773 r., Biblioteka Litewskiej Akademii Nauk, Wilno [dalej: BLAN], F. 273-2440, k.1-5, co najmniej 63 podpisy złożono powtarzającymi się charakterami pisma. Nie zawsze jednak podpisywano $w$ ten sposób osoby nieobecne. Ponieważ tylko przy 6 nazwiskach występują krzyżyki, można mniemać, że przynajmniej część podpisów złożono na prośbę wstydliwych analfabetów, nie chcących ujawniać swego poziomu opanowania pisma. Kwestia wymaga staranniejszego prześledzenia.

3 Archiwum Główne Akt Dawnych, Archiwum Radziwillów [dalej: AGAD, AR] II, nr 583, s. 7.

AGAD, AR II, nr 584, s. 4.

${ }^{5}$ Akty otnosiaszczijesia k istorii Zapadnoj Rossii, t. III, S. Peterburg 1848, s. 138; I. I. L a p p o, Wielikoje Kniażestwo Litowskoje wo wtoroj polowinie XVI stoletija. Litowsko-russkij powiet $i$ jego siejmik, Jurjew 1911, s. 290-291.

${ }^{6} \mathrm{Nie} z$ znaczy to bynajmniej, że - jak sądził Z. Góralski w zawierającej liczne i poważne błędy pracy Urzędy i godności w dawnej Polsce, Warszawa 1983'19982, s. 209 - na Litwie, [...] jak wiemy, nie bylo starostów. Starostowie oczywiście byli w każdym powiecie, w stolicach województw zaś funkcje ich - zasadniczo - pełnili wojewodowie.
} 
Jest to o tyle ważne, że część badaczy sejmików koronnych sądzi, iż na Litwie [...] marszalkowie urzędowali stale ${ }^{7}$. Pogląd ten, wygłaszany od dwustu lat, nie jest - jak widać - zupełnie ścisły. Wynikał on zapewne z nieodróżniania marszałków sejmikowych (directorów) od marszałków powiatowych.

I. I. Łappo uważał, że w XVI w. szlachta Wielkiego Księstwa Litewskiego nie wybierała sejmikowych marszałków, lecz milcząco uznawała, że to najgodniejsi - a więc senatorowie - mogą i powinni kierować sejmikowymi obradami. W następnych zaś stuleciach directorów takich zgromadzeń obierano ${ }^{8}$. Henryk Wisner badający sejmikową działalność i organizację w pierwszej połowie XVII w. stwierdził, że przybytym na sejmik przewodniczyl dyrektor wybierany większościq glosów.

2. Zagajenia sejmiku dokonywał - jak zauważył zajmujący się zasadniczo osiemnastowiecznymi sejmikami Korony Adam Lityński - najstarszy świecka godnościq senatorska (a więc nie zagajali senatorowie duchowni), lub urzędem wśród zebranych ${ }^{10}$. Zasadę tẹ potwierdzila dla Wielkiego Księstwa Litewskiego konstytucja sejmu koronacyjnego 1764 r. ${ }^{1 "}$ Jej przestrzegania dowodzi zaś Diariusz Marcina Matuszewicza ${ }^{12}$. Dlatego też w 1757 r., podczas sejmiku deputackiego, staraly sie strony o chorqziego, bo on zagajal jako pierwszy urzednik sejmiki $i^{13}$. Z kolei w 1755 r. stronnictwo dworskie pilnowało najpierwszego urzędnika należącego do konkurencyjnej partii, obawiając się „kradzieży” sejmiku: zagajenia go w tajemnicy przed konkurencją i swobodnego mianowania, w jej nieobecności, posłów czy deputatów ${ }^{14}$. Reguła ta nie była jednak wolna od wyjątków. W 1681 r., w Wilnie: Na poczq̨tku zagail sejmik $J M P$ choraży wileński, zaraz zgodnie JMP wojew[ode] wileńskiego za direktora obrano $^{15}$. W $1761 \mathrm{r}$. zaś partia radziwillowska obawiała się, aby sejmiku brzeskiego nie zagaił wojski powiązany z Czartoryskimi. W mieście przebywał

${ }^{7}$ W. Kriegseisen, Sejmiki Rzeczypospolitej szlacheckiej w XVII i XVIII wieku, Warszawa 1991 , s. 54

${ }^{8}$ I. I. Łap po, Wielikoje Kniażestwo..., s. 567-570.

${ }^{9} \mathrm{H}$. W i s n e r, Sejmiki litewskie w czasach Zygmunta III $i$ Wladyslawa IV. Konwokacja wileńska oraz sejmiki przedsejmowe $i$ relacyjne, Miscellanea Historico-Archivistica 1989, III, s. 59.

${ }^{10}$ A. Lity ński, Organy kierujq̨ce obradami sejmików 1764-1794 (na przykladzie sejmików województwa plockiego), [w:] $Z$ dziejów prawa Rzeczypospolitej Polskiej, red. A. Lityński, Prace Naukowe Uniwersytetu Sląskiego [Katowice] 1991, 200, s. 66.

"VL VII, 388.

12 M. M atuszewicz, Diariusz życia mego, opr. B. Królikowski, komentarz: Z. Zielińska, t. I, Warszawa 1986: s. 230, 346, 419, 629; t. II, Warszawa 1986: s. 10, 54, 81, 136, 438, 449.

${ }_{13}$ Ibidem, t. I, s. 759. Podobne staranie miało miejsce w 1759 r., ibidem, t. II, s. 54.

14 Ibidem, t. I, s. 467.

is Rossijskij Gosudarstwiennyj Archiw Driewnich Aktow, Moskwa [dalej: RGADA], f. 389, nr 581, k. 634 . 
wprawdzie starosta, który winien - jako wyższy godnością - otwierać sejmik. Jeśli stronnikom Czartoryskich udałoby się przeprowadzić sejmik w tajemnicy przed konkurencją (a należał do niej i starosta), mogliby wówczas przeforsować swoich deputatów ${ }^{16}$. Widać więc, że od zasady ogólnej możliwe były odstępstwa. Osoba zagajającego byla o tyle istotna, że podawal on do laski kandydata na marszałka, co bywało decydujące w określonych konfiguracjach politycznych ${ }^{17}$. Wyjątkiem był również czas konfederacji - wówczas sejmiki zagajał marszatek konfederacki ${ }^{18}$.

Można też zauważyć, że przed wydaniem konstytucji 1764 r. zagajenia dokonywali, choć zdarzało się to nieczęsto, również senatorowie duchowni - ordynariusze diecezji wileńskiej i żmudzkiej, właściwych dla miejsc sejmikowania ${ }^{19}$. Spotykało się to jednak $\mathrm{z}$ oporami ich politycznych konkurentów ${ }^{20}$.

W kwestii zagajania sejmików wątpliwości nie ma. Budzi je natomiast problem kierowania ich obradami.

3.1. W stolicach województw sejmikowymi obradami kierowal wojewoda, jeśli tylko brał udzial w posiedzeniu. Tak więc Jan Antoni Chrapowicki jako wojewoda witebski w latach 1671-1685 - wedle oceny Tadeusza Wasilewskiego - przewodniczyl stale jako dyrektor sejmikom witebskim ${ }^{21}$. Krótka lista sejmikowych directorów przytoczona przez I. Lappę wskazuje, że częstokroć byli nimi właśnie najwyżsi urzędnicy województwa: wojewodowie i kasztelanowie ${ }^{22}$. W 1668 r., w Wilnie przy zgromadzeniu sie na miejscu consultandi obrany unanimi consensu et voto za directora sejmiku JMX Biskup Wileński i przy nim zostala directia jako przy pierwszym WXL $i$ w[ojewó]dztwa wileńskiego senatorze ${ }^{23}$. Można przypuszczać, że na podobnej zasadzie sprawował w $1626 \mathrm{r}$. dyrekcję sejmiku nowogródzkiego metropolita unicki Józef Welamin Rutski, choć nie byl senatorem ${ }^{24}$. W listopadzie $1693 \mathrm{r}$. doszło do rozdwojenia sejmiku żmudzkiego. Relacja $\mathrm{z}$ przebiegu tego zgromadzenia stwierdzała, że początkowo Pac starosta jako zwyczajny

${ }^{16}$ M. Matuszewicz, Diariusz..., t. II, s. 130.

${ }^{17}$ Ibidem, t. II, s. 438, 449.

${ }^{18}$ A. Lity ński, Organy..., s. 66-67; np. Matuszewicz, Diariusz..., t. II, s. 555, Litewskie Centralne Archiwum Historyczne, Wilno [dalej: LCIA], SA 5966, k. 51.

19 M. M atuszewic z, Diariusz..., t. II: s. $449,451,453$.

${ }^{20}$ Ibidem, t. II, s. 486-488.

${ }^{21}$ J. A. Chrapowicki, Diariusz, cz. 1: lata 1656-1664, opr. i wstęp: T. Wasilewski, Warszawa 1978, s. 60.

${ }^{22}$ I. I. Ł a p po, Wielikoje Kniażestwo..., s. 571.

${ }^{23}$ AGAD, AR II, nr 1540.

${ }^{24}$ Zob. H. W is ne r, Przedsejmowy sejmik nowogródzki w latach 1607-1648, PH 1978, LXIX, z. 4, s. 680 , tab. 3 . 
gospodarz zasiadl w pierwszym kole ${ }^{25}$. Wydawca opisu - Gintautas Sliesoriūnas sądzi, że jego autor wykazywał sympatiç dla Sapiehów. Co najmniej równie wyraźnie widać jednak przekonanie, że jedyny senator żmudzki - starosta, jest zwyczajnym gospodarzem tego sejmiku. Nowogródzki sejmik deputacki odbył się w 1697 r. pod dyrekcją kanclerza litewskiego Dominika Mikołaja Radziwiłła $^{26}$. W roku następnym sejmikiem tym kierował kuchmistrz litewski ${ }^{27}$. Ten sam dygnitarz był dyrektorem sejmiku nowogródzkiego 25 sierpnia $1697 \mathrm{r}^{28}$ Ponieważ opisujący $\mathrm{w}$ swoim diariuszu wszystkie trzy zjazdy Stanisław Niezabitowski nie wspomina o nikim poważniejszym, przyjąć można, że obradami kierował właśnie najgodniejszy z obecnych w Nowogródku.

3.2. W XVII i XVIII stuleciu obradami sejmików powiatów nie będących stolicami województw kierowali zazwyczaj marszałkowie powiatowi ${ }^{29}$. Było to efektem ich tradycyjnie wysokiej pozycji. Wywodzili się bowiem z marszałków nadwornych, przydzielanych $w$ drugiej połowie XVI w. do poszczególnych powiatów. Statutowe przepisy i przywileje nadające ten urząd wskazywały na jego znaczącą rolę i niemałe kompetencje. Hospodar zobowiązywał się w II Statucie (III, 5): ...ksiqżęta, pany, marszalki i inne wszystkie urzędniki ziemskie $i$ dworne wedle starodawnego obyczaju mamy listy naszemi na takowy walny sejm wzywac ${ }^{30}$. Z kolei nadanie Zygmunta Augusta z 12 stycznia 1567 r. dla marszalka powiatu bielskiego precyzowało: Kotoryj wrad marszalkostwo pan Adam Kosinskij dierzati na dwore naszom $i$ też gdy budet na sojmiech walnych $i$ na sojmikoch powietowych $i$ na inych zjezdziech ziemskich majet sia siusznie raditi $i$ sprawowati potomu, jako $i$ inyje marszalki naszi $i z$ wladnostiu wszelakoju, $w$ statutie opisanoju ${ }^{31}$. III Statut wyznaczał marszałkom poczesne miejsce na sejmiku - tuż za wojewodą i kasztelanem (III, 6). Również przywilej z 14 lutego 1606 r. na marszałkostwo powiatu wołkowyskiego dla Mikołaja Wolskiego głosil: ...powinien wota na wszeliakich zjezdiech, sojmikoch zwyklym sposobom rozdawati ${ }^{32}$. Wysoka pozycja marszałka wynikała jednak nie tylko z przepisów statutowych, lecz i z realiów struktury

${ }^{25} \mathrm{G}$. S 1 ies oriūnas, Iš Žemaitijos seimeliu istorijos: $1693 \mathrm{~m}$. lapkrilio $10 \mathrm{~d}$. Žemaitijos seimelis, Žemaič-iut praeitis 1998, VIII, s. 32.

${ }^{26}$ St. Ni z za bit ow ski, Dzienniki 1695-1700, wyd. A. Sajkowski, Poznań 1998, s. 141.

27 Ibidem, s. 183.

28 Ibidem, s. 205.

${ }^{29}$ A. B. Zak r zew ski, Marszalek powiatowy Wielkiego Ksiestwa Litewskiego - marszalkiem sejmikowym (XVI -XVIII w.), [w:] Parlament, prawo, ludzie, Warszawa 1996, s. 357-361.

${ }^{30}$ Tekst II Statutu: Pomniki prawa litewskiego z XVI wieku, wyd. F. Piekosiński, Archiwum Komisji Prawniczej 1900, VII, s. 46. Cyfra rzymska oznacza numer rozdziału, arabska - numer artykułu Statutu.

${ }^{31}$ M. Ljubawskij, Litowsko-russkij siejm, Moskwa 1900, s. 731, przyp. 496.

32 A. R a d a m an, Sejmiki $i$ zjazdy szlacheckie województwa nowogródzkiego $w$ drugiej polowie $X V I$ wieku, przyp. 30 (w druku). 
administracyjnej Wielkiego Księstwa. Decydującą rolę odegralo zapewne to, iż zgromadzenia powiatowe nie należały do górnych sejmików Wielkiego Księstwa. Stosunkowo rzadko przybywali tam więc senatorowie. Również starostowie, którymi najczęściej bywali magnaci, wybierali sejmiki ważniejsze - w stolicach województw. W obradach sejmiku powiatowego dominowal więc marszałek powiatowy - najwyższy rangą $\mathrm{z}$ obecnych podczas zjazdu urzędników miejscowych. Skrajnym wyrazem tej praktyki było ujęcie laudum wiłkomierskiego z 20 lutego $1671 \mathrm{r}$. Nie przybył wówczas marszałek, przewodniczył więc najwyższy z obecnych urzędników: Michal Dowmont Siesicki choraży wilkomirski jako direktor na miejscu JMP Marszalka - jak podpisał się pod dokumentem ${ }^{33}$. Zdarzały się jednak wyjątki; najczęściej - gdy na sejmik przybywali senatorowie lub dygnitarze. Wówczas to oni, pomimo obecności marszałków powiatowych, przewodniczyli sejmikom ${ }^{34}$. Sejmikowi wiłkomierskiemu w listopadzie $1686 \mathrm{r}$. przewodniczył wojewoda miński i starosta wilkomierski Michał Dowmont Siesicki ${ }^{35}$. Sejmikiem oszmiańskim w 1713 r. kierowal - pomimo obecności marszałka powiatowego ${ }^{36}$ - tamtejszy starosta, wojewoda miński Krzysztof Zenowicz ${ }^{37}$.

Jeśli na sejmikach brakowało senatorów lub dygnitarzy, sięgano po urzędników ziemskich. Gdy zaś brakowało urzędników bliższych początku hierarchii, sięgano do jej końca. Stąd też w 1664 r. na przedsejmowym sejmiku starodubowskim stanowisko to objął tamtejszy wojski Samuel Hieronim Kociełl. W tym egzulanckim zjeździe udział brało zresztą - jeśli wierzyć podpisom $w$ instrukcji - jeszcze tylko dwóch urzędników powiatu: sędzia grodzki i skarbnik ${ }^{38}$. W 1674 r. podczas sejmiku gromnicznego w Wilkomierzu - jak pisał tamtejszy lowczy - Jan Władysław Poczobut Odlanicki - ze sie przebralo urzedników ziemskich $i$ mnie upraszali na dyrektora. Nie postrzeglszy się, wymówilem sie, czegom potem żalowa ${ }^{\beta 9}$.

Tak więc dyrekcję sejmiku często powierzano najwyższemu godnością spośród obecnych. Nawet jeśli była to godność niespecjalnie wysoka.

4. Była to jednak prawidłowość z licznymi nieraz wyjątkami. Przyczyn ich możemy się najczéściej tylko domyślać. Nie najgorzej ilustrują ten aspekt sejmikowej polityki Pamiętniki Krzysztofa Zawiszy. Ich autor - wówczas

${ }_{33}$ BLAN, F. 207-1825.

${ }^{34}$ A. B. Zak r zew sk i, Marszalek powiatowy..., s. 359-360.

${ }^{35}$ Biblioteka ZN im. Ossolińskich, rkps II 13000 , s. 105-106.

${ }^{36}$ BLAN, F. 207-1825, k. 19v., 4 XII 1713 r.

${ }^{37}$ BLAN, F. 207-1825, k. 18v., $28 \times 1713$ r.

${ }^{38}$ BLAN, F. 198-10, k. 4. Wykaz Urzędnicy centralni $i$ dostojnicy Wielkiego Ksiestwa Litewskiego, opr. H. Lulewicz, A. Rachuba, s. 215, podaje, iż S. Kociełł był wojskim do 1658 r.

${ }^{39}$ J. W. Poczobut Odlanicki, Pamiętnik, opr. A. Rachuba, Warszawa 1987, s. 273. 
starosta miński - często kierował, jako najstarszy obecny urzędnik, miejscowymi sejmikami ${ }^{40}$. W 1696 r. na obrady zjechal podczaszy Wielkiego Księstwa Marcin Kryszpin Kirszenstein $i$ on objąl - jako godniejszy - dyrekcję. Sytuacja powtórzyła się na sejmiku gromniczym roku następnego. Nieco później podczaszy awansował na kasztelanię trocką. Jednak podczas mińskiego sejmiku gromnicznego 1698 r. dyrekcję sprawował, mimo imci p. Kryszpina kasztelana trockiego, starosta miński. Czego nie omieszkal w zapiskach dla potomnych zaznaczyć... W listopadzie tego samego roku kolejnym sejmikiem mińskim kierowal chorąży miński Jan Zawisza - brat Krzysztofa. Starosta spóźnił się bowiem dwa dni na rozpoczęcie obrad. Dyrekcję mińskiego sejmiku gromnicznego w 1700 r. sprawowal z kolei, pomimo obecności K. Zawiszy, podczaszy miński Władysław Krajewski ${ }^{41}$.

Dyrekcję obejmowali niekiedy urzędnicy miejscowi, nie zaś obecni na miejscu ministrowie czy też senatorowie $z$ innych województw. Sejmikiem połockim 5 marca 1683 r. kierowal tamtejszy kasztelan Jan Korsak, choć obecny był wyższy godnością wojewoda trocki Marcjan Ogiński ${ }^{42}$. Temu samemu zgromadzeniu 19 maja 1725 r. nie przewodniczył Stanisław Denhoff tamtejszy wojewoda, lecz direktor sejmiku podwojewodzi Walerian Antoni $\dot{Z ̇ a b a}^{43}$. W Pińsku 4 czerwca 1692 r. sejmikiem kierował marszałek piński Maciej Puzyna, nie zaś marszałek wielki litewski Jan Karol Dolski ${ }^{44}$. Z kolei directorem sejmiku lidzkiego 3 lutego 1683 r. był starosta słonimski Stefan Frąckiewicz Radzimiński. Funkcji tej nie pełnił natomiast, również podpisany na instrukcji, właściwy terytorialnie starosta lidzki Kazimierz Frąckiewicz Radzimiński ${ }^{45}$. Wynikało to - jak sądzi Andrzej Rachuba - $\mathrm{z}$ różnicy wieku, przewagi majątku i pozycji społecznej pierwszego z krewniaków.

W Brześciu w 1752 r. dyrekcję objąl wojewoda mścislawski Ignacy Sapieha, pomimo obecności jego starszego brata, właściwego terytorialnie wojewody brzeskiego - Karola Sapiehy ${ }^{46}$. Analogiczna sytuacja powtórzyła się w Brześciu sześć lat później ${ }^{47}$. O ile można założyć, że Karol Sapieha dystansował się wówczas wobec nieakceptowanych przez siebie kandydatów do Trybunału, to trudno uzasadnić rezygnację z kierowania sejmikiem wcześniejszym.

Jeśli byli godniejsi, a directorem zostawal urzędnik niższy rangą, podpisywał się on najczęściej w dalszej kolejności. Tak więc sejmikami wileńskimi

40 Pamietniki Krzysztofa Zawiszy, wojewody mińskiego (1666-1721), wyd. J. Bartoszewicz, Warszawa 1862, s. 37, 44.

${ }^{41}$ Ibidem, s. 48, 49, 55, 62, 73.

${ }^{42}$ RGADA, f. $389, \mathrm{nr} 581$, k. 679 v. (podwójna paginacja).

${ }^{43}$ BLAN, F. 198-10.

${ }^{44}$ RGADA, f. 389, nr 581, k. 773 (podwójna paginacja).

${ }^{45}$ RGADA, f. 389 , nr 581, k. 671 v. (podwójna paginacja).

${ }^{46}$ M. M at u s zew ic z, Diariusz..., t. I, s. 344-345.

${ }^{47}$ Ibidem, t. II, s. 6-8. 
w 1613 r. kierowali: styczniowym - podkomorzy oszmiański i pisarz skarbowy Jan Dołmat Isajkowski ${ }^{48}$, listopadowym - podkomorzy wileński Malcher Szemiot ${ }^{49}$. W obydwu sejmikach uczestniczyli jednak senatorowie: w styczniu - kanclerz, biskup wileński oraz podskarbi wielki; w listopadzie - tenże biskup, wojewoda nowogrodzki oraz podkanclerzy. Dlatego też obydwaj marszałkowie musieli zadowolić się podpisem na czwartym miejscu. Podobnie w 1624 r., w Nowogródku: director - sędzia ziemski nowogródzki podpisal się, wobec obecności metropolity Rutskiego i wyższego w hierarchii ziemskiej miejscowego chorążego, jako trzeci w kolejności ${ }^{50}$.

5. W dobrym tonie było - jak się wydaje - uproszenie przyszłego marszałka o przyjęcie godności. Tak właśnie powierzono ją w 1711 r. w Grodnie Zygmuntowi Buchowieckiemu: za dyrektora obrad naszych uprosiwszy - ujęło laudum $^{51}$. Ten sam rytual zastosowano w Wilnie, w 1731 r. Podczas następujących po sobie dwóch lutowych sejmików - gromnicznego i boni ordinis - obydwu kierujących obradami wybrano, uprosiwszy za dyrektora i marszalka ${ }^{52}$. Również w 1745 r. kasztelan brzeski Stefan Tarkowski zagail tandem kasztelan sejmik, a gdy go zaraz do marszalkowstwa urzednicy zapraszać poczęli... ${ }^{53}$. Podobnie szlachta brasławska, protestująca w $1756 \mathrm{r}$. przeciw kierowaniu sejmikiem przez stronnictwo Jana i Józefa Ciechanowieckich, stwierdzała, że stronnicy tych ostatnich zaczęli jednego $\mathrm{z}$ nich do dyrekcji zapraszać $c^{54}$. Ten element sejmikowej kultury politycznej koresponduje $\mathrm{z}$ przysięga deputata Trybunału: ...izem o to obieranie siebie, sam ani przez kogo innego sie nie staral ${ }^{55}$. Dlatego jednym $\mathrm{z}$ zarzutów wobec kierującego sejmikiem kowieńskim w 1753 r. kasztelana witebskiego Szymona Syrucia było, że sam się zaproponował niepraktykowanym zwyczajem przez samego siebie do dyrekcji za kandydata ${ }^{56}$.

$\mathrm{W}$ jaki sposób dochodzilo do wyboru sejmikowego directora - w większości wypadków - nie bardzo wiadomo. Osiemnastowieczne compendia naświetlają - nader ogólnikowo - tylko stosunki koronne. Władysław Lubieński pisał: Senator pierwszy zagaja, a potym przystepujq do elekcji marszalka, kryskujac sie przez vota dane, abo sie też zgodza na podanego przez senatora zagajajqcego ${ }^{57}$.

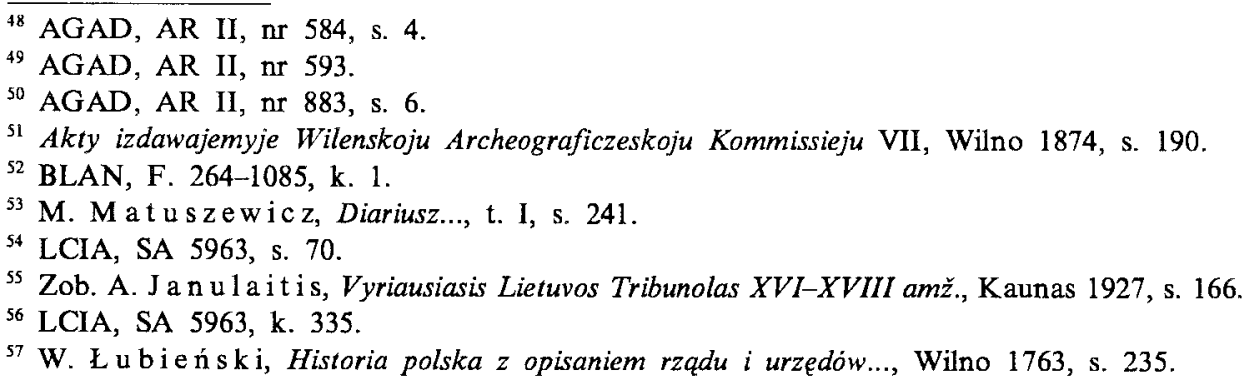


Ignacy Krasicki stwierdzał zaś: $\mathrm{Na}$ wszelkich sejmikach obieraja najprzód marszalków, do prowadzenia porzqdku tegoż zjazdu... ${ }^{58}$ Litewskich realiów żaden z nich nie opisywał. Stąd skazani jesteśmy na niezbyt liczne wzmianki naświetlające kulisy sejmikowych dyrekcji nie sprawowanych przez najwyższego rangą urzędnika. Dokumenty sejmików trockich ${ }^{59}$ wskazują na istnienie tam w XVIII stuleciu stronnictwa składającego się z najwyższych urzędników ziemskich. Grupa ta tylko niekiedy dopuszczała do sejmikowej dyrekcji któregoś z niższych urzędników. Najczęściej wówczas, gdy jej pierwszoplanowi członkowie kandydowali do funkcji deputatów Trybunału.

Brzeskim sejmikiem poselskim w $1744 \mathrm{r}$. kierował tamtejszy sędzia grodzki Michał Buczyński, którego inspirowana przez M. Matuszewicza szlachta zaniosla na ręku do kościola [...] i malo co dawszy zagaić Tarkowskiemu, kasztelanowi brzeskiemu, osadzila na krześle marszalkowskim ${ }^{60}$. Dwa lata później dyrekcję tamtejszego sejmiku deputackiego objął, pomimo obecności miejscowego podkomorzego - od szlachty wezwany - M. Matuszewicz, wówczas tylko pisarz grodzki ${ }^{61}$. Pamiętnikarz ten podaje więcej przykładów takiego wyboru directora $^{62}$. Najczęściej nie był to wybór spontaniczny, lecz efekt zakulisowych działań powiatowego polityka, czy też jego magnackiego mocodawcy ${ }^{63}$. W 1761 r. posłami z Kowna wybrano Marcina Matuszewicza - bez żadnej najmniejszej kontradykcji ${ }^{64}$, i Józefa Kossakowskiego. Ten ostatni stwierdził: ...i zostalem wybrany unanimitat $[!]^{65}$. Do wzmianek o wyborze unanimitate, sine ulla contradictione należy jednak podchodzić z dużą ostrożnością. Wskazywały one jednak na częsty wybór na zasadzie zgody. Było to następstwem zarówno dominującej w kulturze politycznej epoki zasady zgody, jak i uciążliwości trwającego niekiedy parę dni kreskowania ${ }^{66}$. Na niechęć opinii szlacheckiej do tej formy i wyższość zgodnej elekcji wskazuje choćby Księga pamiętnicza Stefana Franciszka Medekszy. Pamiętnikarz z lubością konstatował na jej kartach swój wybór zgodnie od wszystkich lub też - bez kresek ${ }^{67}$.

${ }^{58}$ I. K rasicki, Zbiór potrzebniejszych wiadomości porzqdkiem alfabetu ulożonych, t. II, Warszawa-Lwów 1781, s. 128.

${ }^{59}$ Głównie z ksiąg grodzkich trockich: LCIA, SA 5958, 5959.

${ }^{60}$ M. M a tuszewic z, Diariusz..., t. I, s. 230.

${ }^{61}$ Ibidem, t. I, s. 255.

${ }^{62}$ Ibidem, t. I, s. 203, 272.

${ }^{63}$ Podstawowe ujęcie: Z. Zielińska, Mechanizm sejmikowy i klientela radziwillowska za Sasów, PH 1971, LXII, z. 3, s. 396-419.

${ }^{64}$ M. M a tu szewicz, Diariusz..., t. II, s. 145.

${ }^{65}$ Pamiętniki Józefa Kossakowskiego, wyd. A. Darowski, Warszawa 1891, s. 24.

${ }^{66}$ Zob. A. B. Zakrzewski, Ograniczenie przez sejmiki Wielkiego Ksiestwa Litewskiego monarszego prawa mianowania urzędników sqdowych, XVI-XVIII w., [w:] Lietuvos valstybe XII-XVIII a., red. Z. Kiaupa, A. Mickevičius i J. Sarcevičienè, Vilnius 1997, s. 183 i tamże literatura.

${ }^{67}$ St. Fr. M ed eks za, Ksiega pamiętnicza wydarzeń zaszlych na Litwie 1654-1668, wyd. Wł. Seredyński, t. III: Scriptores Rerum Polonicarum, Kraków 1875, s. 8, 10, 11, 13. 
Sejmikami kowieńskimi czterdziestych lat XVIII stulecia przez pewien czas na przemian kierowali pogodzeni konkurenci do powiatowych godności: ...dyrekcji sejmiku ustapil Zabiello Siruciowi, a Siruć pretensji do marszalkowstwa powiatowego Zabielle, tymczasem nim elekcja marszalkowska nastapi, alternate dyrekcji sejmikowych obydwa obserwować między soba mieli ${ }^{68}$.

6. Jeśli pojawiali się chętni do objęcia dyrekcji, a najgodniejszy $\mathrm{z}$ obecnych mimo to zasiadał na miejscu przewodniczącego - dochodziło do kontrowersji.

Wojewoda miński Aleksander Ogiński chciał w 1647 r. kierować sejmikiem trockim, aby wypromować na poselstwo swego syna. Szlachta domagała się more solito wyboru dyrektora spośród siebie. Na to wojewoda odpowiedział, $i \dot{z}$ we zwyczaju tego nigdy nie bywalo i nigdzie nie masz per vota dyrektora obiera $^{69}$. Podobnie w Nowogródku, w 1689 r. nowo mianowany wojewoda nowogródzki Bogusław Uniechowski, na tamtejszym sejmiku przeciw kontradykcyji [...] wielu braciej dyrekcyja sobie przywlaszczy ${ }^{10}$. Jednemu z kolejnych wojewodów nowogródzkich - Mikołajowi Faustynowi Radziwiłłowi - zarzucano w 1741 r., że podczas tamtejszego sejmiku wynoszqc sie ultra aequalitatem a liberum veto unicam wolności szlacheckiej scintillam gaszqc [...] miejsce dyrektorskie violenter zasiadszy bez wotowania wszystkich obywatelow tego województwa ${ }^{71}$. Jeśli nie dało się doprowadzić do kompromisu, zgłaszano protestację, sejmiki rozdwajano bądź zrywano. Takie były zapewne kulisy zrywania w 1698 r. - dzień po dniu - trzech nowogródzkich sejmików elekcyjnych ${ }^{72}$.

7. Czy nie było więc zasadą sprawowanie sejmikowej dyrekcji przez najgodniejszego z obecnych, wyjątkiem zaś - wybór zgodny lub kreskami? Do wyboru dochodziło najpewniej wówczas, gdy pojawiała się konkurencja do dyrekcji sejmiku, autorytet zaś najstarszego urzędnika nie zawsze wystarczał, by utrzymać to stanowisko. Przypuszczać więc można, że najwyższy urzędnik obecny podczas obrad nie zostawał directorem, jeśli nie był $w$ stanie zapanować nad nierzadko przeciwną mu szlachtą, albo rezygnował $\mathrm{z}$ sejmikowej dyrekcji w zamian za zgodę na mandat poselski lub funkcję deputata.

\footnotetext{
${ }_{68}^{68}$ M. Matuszewicz, Diariusz..., t. I, s. 156.

${ }^{69}$ I. I. La p p o, Wielikoje Kniazestwo..., s. 560, przyp. 4. Posłowie tak wybrani nie utrzymali się w czasie rugów poselskich, zob. A. S. R adziwill, Pamiętnik o dziejach $w$ Polsce, t. III, opr. A. Przyboś, R. Żelewski, Warszawa 1980, s. 23, 26.

${ }^{70}$ Cyt. za: W. Kriegseisen, Sejmiki Rzeczypospolitej..., s. 184. Tamże obszerny opis tha konfliktu.

${ }^{11}$ RGADA, f. 1473, op. 1, nr 1082, k. 1.

${ }^{72}$ St. Nie zabitowski, Dzienniki $1695-1700$, s. 199.
} 
Czasami znów sprawował nieformalny nadzór nad obradami, godząc się, aby formalne ich przewodnictwo sprawował ktoś mniej eksponowany. Niekiedy, nie ingerując w przebieg sejmiku, ograniczal się tylko do mniej lub bardziej dyskretnego zaznaczenia obecności.

Przemawia za takim ujęciem - podsumowująca i korygująca, celem usprawnienia obrad, dotychczasową praktykę - konstytucja sejmu koronacyjnego $1764 \mathrm{r}$. Stanowiła ona, że w dzień sejmiku nie predzej jak o godzinie ósmej z rana, zebrawszy sie na sejmik, miejsca swoje kolo stolu urzędnicy zasiq̨ść, a nobilitas nie cisnqwszy sie do stolu, stalla urzędników otoczywszy, sejmikować zacznq; $i$ takowy sejmik przez pierwszego senatora świeckiego, a $w$ niebytności senatora, przez pierwszego urzednika przytomnego zagajony, et sub praesidentia onego, nie obierając juz odtad dyrektorów sejmiku, odprawowany byc powinien ${ }^{73}$. Konstytucja ta początkowo dotyczyła tylko sejmików elekcyjnych i deputackich. W $1768 \mathrm{r}$. zasady jej rozciągnięto na pozostałe Sejmiki $\mathrm{i}^{74}$ i stosowano również podczas sejmików gospodarczych ${ }^{75}$ : przedsejmowych ${ }^{76}$.

Pogląd taki poprzeć może również obserwacja Jerzego Urwanowicza, badającego koła wojskowe. Stwierdził on, że ich wzorcem były koła obywatelskie $^{77}$. Obradami kół wojska litewskiego (koronnego również) kierowali, w nieobecności hetmana, najwyżsi rangą oficerowie lub dygnitarze wojskowi ${ }^{78}$. Przeciw - przemawia z kolei przykład sejmików szkolnych Akademii Wileńskiej w połowie XVIII w., będących elementem wychowania obywatelskiego: tam marszałków wybierano ${ }^{79}$.

Być może zasadę wyboru sejmikowego dyrektora per vota stosowano tylko w niektórych okresach, w pewnych sejmikach. Wynikało to zapewne z układu sił w polityce wojewódzkiej i powiatowej. Przyczyn litewskiej odmienności wobec koronnej praktyki doszukiwać się można w strukturze społecznej Wielkiego Księstwa. Polegała ona na zdecydowanie silniejszej pozycji magnaterii i - silniejszych niż w Koronie - zależnościach klientarnych.

Przedstawiona hipoteza wymaga jeszcze sprawdzenia na szerszej podstawie w miare jednorodnych źródeł.

${ }^{73}$ VL VII, 388.

74 VL VII, 624.

${ }^{75}$ LVIA, SA 5917, k. 709, 713, 832, 848v.

${ }^{76}$ LVIA, SA 5917, k. 856; SA 5918, k. 5v., 136-145v. Marszałkami sejmików przedsejmowych, w latach 1788 i $1790 \mathrm{w}$ Wilnie, Grodnie, Wiłkomierzu, Lidzie, oraz 1788 r. w Trokach i w 1790 r. w Kownie byli najwyżsi godnością spośród obecnych, BLAN, F. 233-125, F. 233-126. Zakładamy, że na instrukcjach podpisali się najwyżsi godnością.

77 J. U rwanowicz, Wojskowe, sejmiki". Kola w wojsku Rzeczypospolitej XVI-XVIII wieku, Dissertationes Universitatis Varsoviensis 446, Białystok 1996, s. 189.

78 Ibidem, s. 68 i n.

${ }^{79}$ Ks. L. Pi e chnik, Odrodzenie Akademii Wileńskiej 1730-1773, Rzym 1990, s. 72. 